\title{
TESTING AND RATING CONVECTORS
}

\author{
Commercial Standard CS140-47
}

(Issued March 3, 1947)

Effective Date for New Production from March 1, 1948

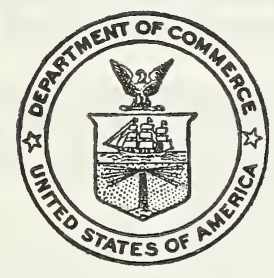

A RECORDED VOLUNTARY STANDARD

OF THE TRADE

UNITED STATES DEPARTMENT OF COMMERCE

W. AVERELL HARRIMAN, Secretary 
Commercial Standards are voluntary standards of the trade developed through concerted action of those directly concerned, and issued by the U.S. Department of Commerce upon written evidence of their acceptability to the trade. They are initiated by written request from a responsible element of business to the Division of Trade Standards of the National Bureau of Standards. The -Division of Trade Standards acts as a coordinating and fact-finding agency in ascertaining the desires of all concerned.

The Federal Government exercises no regulatory authority in the enforcement of Commercial Standards. In accepting a Commercial Standard, the producer, distributor, or user says in effect that he considers it a useful standard of practice, and plans to utilize it as far as practicable in his business, reserving the right to depart from the standard so long as no deception results from such departure. When reference to a Commercial Standard is made in contracts, labels, invoices, or advertising literature, however, the provisions of the standard are enforcible through usual legal channels as a part of the sales contract.

Organized in 1927, the Division of Trade Standards has assisted many industries in the development of Commercial Standards for a wide variety of commodities. A list of previously established Commercial Standards appears herein.

\section{COMMERCIAL STANDARD FOR TESTING AND RATING CONVECTORS}

On March 15, 1945, at the instance of the Convector Manufacturers Association and the Institute of Boiler and Radiator Manufacturers, a proposed commercial standard for testing and rating convectors was circulated to representative user organizations, testing laboratories, Government agencies, distributors and manufacturers for comment. Following adjustment in the light of comment, a recommended commercial standard was circulated on July 19, 1946, to the entire trade for written acceptance.

The trade has since approved the standard as shown herein for issuance by the U. S. Department of Commerce.

Project Manager: F. E. Powell, assisted by P. S. Murphy,

Division of Trade Standards, National Bureau of Standards.

Technical Advisers: R. S. Dill and H. E. Robinson,

Division of Heat and Power, National Bureau of Standards. 
COMMERCIAL STANDARD CS140-47

for

\section{TESTING AND RATING CONVECTORS}

CONTENTS

Part

1. General

Page

Purpose....

Scope

Definitions

Requirements

2. Methods of testing steam convectors

3. Methods of testing hot-water convectors

4. Methods of rating -

5. Labeling and approvals

\section{GENERAL}

\section{PURPOSE}

1. The purpose of this commercial standard is to establish standard methods of test for the output of convectors, that is, the condensation capacity of steam convectors and the water heat capacity of hot-water convectors, and methods for determining, designating, and guaranteeing convector ratings.

\section{SCOPE}

2. This standard covers definitions, requirements, and methods of testing and rating cast-iron and nonferrous steam and hot-water convectors. It also covers a uniform method of manifesting compliance with the standard and a means for checking convector ratings for approval.

\section{DEFINITIONS}

3. Convector.-The term "convector," as used in this standard, shall apply to any type of steam- or water-heated room heater which operates with gravity recirculated room air, which is surrounded on all sides by an enclosure having an air-inlet opening at its bottom end and an air-outlet opening at its top end, and which is installed inside the heated room or recessed in the wall of the heated room.

4. . Stack height.- "Stack height," as used in this standard, is the vertical distance measured from the lowest point of the main body of the convector to (a) the upper edge of the free openings of a front outlet grille or opening, or (b) the underside of a horizontal top outlet grille, or (c) the center of an inclined outlet grille. 
5. Inside enclosure depth.- "Inside enclosure depth," as used in this standard, is the minimum free distance from the inside of the enclosure front to the inside of the enclosure back, taken at the level of the convector.

6. Inside enclosure length.- "Inside enclosure length," as used in this standard, is the minimum free inside length of the enclosure, taken at the level of the convector. Where baffle plates are used at the end, the inside enclosure length is the minimum distance between the inner edges of such baffle plates.

7. Over-all enclosure height.- "Over-all enclosure height," as used in this standard, is the height from the bottom of the enclosure to its highest point.

8. Opening heights or widths._- "Opening heights or widths" (including inlet and outlet openings or grilles), as used in this standard, is the distance from the lower or front edge of the free opening to the upper or rear edge of the free opening or grille.

9. Free area.- "Free area," as used in this standard, is the total minimum area of the opening, or the openings in the grille, through which air can pass.

10. Capacity.- "Capacity," as used in this standard, is the condensation capacity determined in accordance with the provisions prescribed in part 2 , or the water heat capacity as prescribed in part 3 .

11. Rating.

11a. Top outlet convectors.- The rating of a top outlet convector shall be the capacity as defined in paragraph 10 .

11b. Front outlet convectors.- The rating of a front outlet convector shall be the capacity, as defined in paragraph 10, plus an addition for heating effect not to exceed the percentage show $n$ in table 3 .

11c. Inclined outlet convectors. - The rating of an inclined outlet convector shall be the capacity, as defined in paragraph 10 , plus an addition for heating effect as prescribed in paragraph 34 .

\section{REQUIREMENTS}

12. Rating tests.

12a. Tests for determining steam ratings shall conform to the requirements prescribed in part 2 of this standard.

$12 \mathrm{~b}$. Tests for determining water ratings shall conform to the requirements prescribed in paragraphs $17,17 \mathrm{a}, 17 \mathrm{~b}, 17 \mathrm{c}, 17 \mathrm{~d}, 17 \mathrm{e}$ and in part 3 of this standard.

13. Minimum test capacities.-Tests made for rating purposes shall be conducted with convectors of at least 25 square feet steam (240 Btu per square foot) or water (150 Btu per square foot) capacity, except that convectors of less than 25-square-feet capacity may be used for test if the over-all length of the convector exceeds 45 inches, or if the convector is designed to operate as a unit of one size only.

14. Types and depths. - Each convector type and depth shall be tested.

15. Heights.- Tests shall be conducted with at least two heights of both top and front outlet enclosures for each convector type and each depth. One of the tested enclosures shall be equal to or lower than the lowest height for that type and depth cataloged by the manufacturer. The maximum enclosure height to be tested shall be equal to or higher than the maximum for that type and depth cataloged by the manufacturer. Intermediate sizes may be tested. 
16. Lengths.- One length only of each convector type and depth need be tested.

17. Hot-water tests.-Tests for determining water ratings shall conform to the requirements prescribed in part 3 of this standard.

17a. Water-heating ratings based on a water-temperature drop of $20^{\circ} \mathrm{F}$ through the convector and including a rating for $170^{\circ} \mathrm{F}$ average water temperature shall be published by the manufacturer for each hot-water convector. Tests for these ratings shall be made with a water-temperature drop through the convector of $20^{\circ} \mathrm{F}, \pm 15$ percent, and shall include at least one test made with an average water temperature of not more than $175^{\circ} \mathrm{F}$ nor less than $165^{\circ} \mathrm{F}$.

$17 \mathrm{~b}$. Hot-water tests shall be made at average temperatures within 10 percent of the minimum and maximum temperature listed by the manufacturer.

17c. Tests shall be made with intervals between average water temperature not exceeding $30^{\circ} \mathrm{F}$.

$17 \mathrm{~d}$. If additional rating data for different temperature drops are also published, the temperature drop shall be stated, and tests shall be made within the range and with the temperature intervals prescribed in this paragraph 17. During these tests the temperature drop shall be maintained within 15 percent of the published temperature drop.

17e. If the water convector is similar in design to the steam convector, water ratings may be expressed in Btu per square foot of catalog steam ratings. A water convector is considered similar to a steam convector if the tubes are similarly arranged and if its fins have substantially the same size, shape, thickness, and spacing, and if the total actual heating surface of the water convector does not vary more than 5 percent from the surface of the corresponding size steam convector. Where this similarity exists, only one size of the water convector need be tested for rating. This tested convector shall be of average depth and length, and shall be tested in an enclosure of approximately 26-inch over-all height and of the same style as used for the steam tests of the equivalent size of steam convector. These water tests shall be made for all water temperatures and temperature drops specified in this paragraph 17. (For method of rating untested hot-water convectors, see paragraph $35 \mathrm{~b}$ of part 4 .)

18. Test room or booth.-Testing of steam convectors and hot-water convectors shall be conducted in one of the following types and sizes of room.

18a. Warm-wall booth.

(1) A warm-wall booth is a room with one side open, located in a larger room. The floor of the booth shall be at least 1 foot and not more than 4 feet above the larger room floor. The open side of the booth shall have a shield projecting down 1 foot from the ceiling. The air in the booth shall be free from draft, except that created by the convector under test in the course of its normal operation.

(2) The test booth shall be protected from the influence of uncontrolled heat sources. The distance between any test booth wall and the wall of the surrounding room shall be not less than 2 feet and the ceiling of the test booth shall be not less than 1 foot from the ceiling of the larger room. The air temperature in this larger room shall he taken at 
the mid-point of each of the three closed sides of the test booth at a level of 30 inches above the floor of the test booth at a distance of 12 inches from the test booth walls and shall show a variation not to exceed $\pm 3 \mathrm{deg} F$ during the course of a test. This temperature at no time during the test shall be less than $50^{\circ} \mathrm{F}$.

(3) The convector shall be installed in accordance with the manufacturer's instructions, in an enclosure as furnished by the manufacturer or built to the dimensions and of the material specified by the manufacturer. It shall be located at the approximate center of the wall opposite the open side of the booth, and the back of the enclosure shall be placed tightly against this wall.

18b. Cooled-wall room.

(1) A cooled-wall room is a room with all sides closed, in which the inner portions of walls, ceiling, or floor are cooled by air circulating over the outer surface of the inner wall for the purpose of removing heat and maintaining suitable air temperatures in the test room. The temperature of the inside surfaces of walls, floor, or ceiling at no point shall be lower than $55^{\circ} \mathrm{F}$ during the test.

(2) The convector shall be installed in accordance with the manufacturer's instructions in an enclosure furnished by the manufacturer or built to the dimensions and of the material specified by the manufacturer. It shall be located at the approximate center of a cooled wall. A 1/2inch-thick insulation board of at least the size of the enclosure shall be placed tightly against the wall, and the back of the enclosure shall be placed tightly against this insulation.

(3) The convector shall be set on one piece of nonporous, nonmetallic material of not to exceed 1/4-inch thickness, which is placed against the wall and projects at least 1 foot beyond the front and sides of the enclosure.

18c. Cold room.

(1) A cold room is a room with all sides closed, which has two or more walls exposed to an air space having a temperature less than $50^{\circ} \mathrm{F}$ but not less than $-10^{\circ} \mathrm{F}$. The walls, floor, and ceiling of this test room must be of customary good building construction. The walls, ceiling, and floor exposed to the cold air shall have a heat-transmission coefficient not to exceed $0.27 \mathrm{Btu}$ per square foot per degree Fahrenheit difference per hour. The walls, floor, and ceiling of such a room not exposed to the cold air shall have a total heat exchange not to exceed 5 percent of the convector capacity. At least one of the exposed walls shall have a window of commercial construction and at least 10-square-feet area with the top of the window stool located approximately 30 inches above the floor. The total exposed window and door area shall not exceed 25 percent of the exposed area, including wall, window, and door. 
(2) Convectors shall be installed in accordance with the manufacturer's instructions, in an enclosure furnished by the manufacturer or built to the dimensions and of the mam terial specified by the manufacturer. The back of the enclosure shall be placed tightly against an exposed wall. Convectors with enclosure heights of 26 inches or less shall be located underneath the window center. Convectors with higher enclosures shall be located at an exposed wall, but not immediately in front of the window.

18d. Size and construction.-The test room or booth shall have a floor area of more than 100 square feet and less than 300 square feet, and no side wall shall be less than 9 feet long. The ceiling height shall be not less than 8 feet and not more than 10 feet. The floor shall be tight and constructed of commercial wood flooring. Nonmetallic walls and ceiling shall be used. The inside of the walls and ceiling shall be either plastered or painted with a flat oil paint.

\section{METHODS OF TESTING STEAM CONVECTORS}

19. Test conditions.

19a. Relative humidity and air motion.-It is inadvisable for relative humidity in the test room or booth at the time of test to exceed 75 percent. Air motion shall be limited to natural circulation.

19b. Steam supply.- Steam shall be supplied to the convector at a pressure corresponding to a saturated-steam temperature of not less than $214^{\circ} \mathrm{F}$ nor more than $217^{\circ} \mathrm{F}$ and shall have a superheat of not less than $2 \mathrm{deg} \mathrm{F}$ nor more than $5 \mathrm{deg} \mathrm{F}$. The steam-supply temperature shall be meastred by a thermometer accurate within $1 / 2 \mathrm{deg} F$ directly exposed to the steam and located within 12 inches of the convector. The steam pressure shall be measured by a liquid-filled manometer connected to the supply pipe. The supply piping shall be well insulated and of such size as to cause only a negligible pressure drop between manometer and convector. The piping inside the test room or booth shall be kept to a minimum. (Fig. 1 illustrates a suitable piping arrangement.)

19c. Condensate piping.-The condensate piping shall be well insulated and shall freely drain the condensate from the convector to a receptacle. Suitable seals shall be provided in this condensate pipe to prevent steam from issuing from the end of this piping. This pipe shall terminate outside the test room or booth and be provided with an air vent. Steam which might escape from this vent shall be conducted outside the test room or booth.

19d. Air temperature.-The convector shall be tested with an inlet air temperature of not less than $60^{\circ} \mathrm{F}$ nor more than $75^{\circ} \mathrm{F}$. This temperature shall be measured at three or more points spaced not more than 8 inches apart throughout the length of the inlet-air opening midway between the top and bottom and 18 inches in front of the inlet. 'The outer thermometers shall be not more than 3 inches from the ends of the air inlet. The last 2 inches of the temperature sensitive end, if more than 0.03 inch in diameter, shall be shielded against radiation by bright-metal shields of such construction as not to interfere with the air flow. (See fig. 2 for suggested construction.) The thermometer 1 used in the test shall be accurate within $1 / 2$ deg $F$. The sensitive end of the thermometer shall be "The term "thermometer," as used in this standard, applies to any temperature-measuring device. 
not more than $5 / 16$ inch in diameter. It is recommended that temperature readings be taken in the center of the room or booth at levels of 3 inches, 30 inches, and 60 inches above the floor and 3 inches below the ceiling.

19e. Air venting. - The convector shall be vented continuously during the test by suitable means, and the expelled air, gases, and steam shall be discharged outside the test room. The vent in the condensate line mentioned in paragraph $19 \mathrm{c}$ of this part 2 may be used for this purpose. It is recommended that the air-vent hole be not larger than 0.03 inch in diameter.

20. Test procedure.

20a. Start of test.-The test shall be started only after a state of equilibrium has been reached. Such a state of equilibrium may be considered as obtained if, for a period of at least 30 minutes, the inlet air temperature has not varied more than 1 deg $\mathrm{F}$ and the rate of condensation has not varied more than 3 percent.

20b. Duration of test.-The test shall be conducted for not less than 1 hour.

20c. Condensate.-The total condensate shall be collected and weighed to 0.01-pound accuracy. At least two measurements of condensate should be made at half-hour intervals within the test time, and the condensation rate obtained on these measurements shall not vary more than 3 percent. Intermediate readings shall be taken every 15 minutes during the tests in a warm-wall booth.

$20 \mathrm{~d}$. Temperature readings.-The inlet air and steam temperatures shall be read at least at the beginning and at the end of the test. Intermediate readings shall be taken every 15 minutes during the tests in a warm-wall booth. These readings shall not vary more than a total of $1 \mathrm{deg} \mathrm{F}$. The average of the temperatures shall be used for calculation.

21. No load test.-The condensing capacity of the part of the supply and condensate piping which drains into the condensate collector shall be determined by a separate test, simulating test conditions, and the amount of condensation thus determined shall be deducted from the gross condensation of the convector.

22. Calculation of condensation capacity. - The condensation capacity of a convector under test conditions shall be determined by the formula:

where

$$
H_{t s}=\Pi_{s} \times h_{f !},
$$

$H_{t s}=$ Condensation capacity for test conditions, Btu per hour

$W_{s}=$ Net weight of condensate, expressed in pound's per hour, (gross weight of condensate minus deduction for supply and condensate piping)

$h_{f g}=$ Latent heat of evaporation of steam, corresponding to the saturated steam temperature in the convector during test (see table 1).

TABLE 1.-Latent heat of evaporation of steam

\begin{tabular}{|c|c|c|c|}
\hline Temperature & $\begin{array}{c}\text { Absolute } \\
\text { steam pressure }\end{array}$ & $\begin{array}{c}\text { Absolute } \\
\text { steam pressure }\end{array}$ & $\begin{array}{c}\text { Latent heat } \\
\left(\mathbf{h}_{f_{0}}\right)\end{array}$ \\
\hline${ }^{\circ} \mathrm{F}$ & $l b / \mathrm{sq}$ in & in. Hg & Btu/lh \\
2214 & 15.289 & 31.129 & 969.0 \\
215 & 15.595 & 31.752 & 968.4 \\
216 & 15.901 & 32.375 & 967.8 \\
217 & 16.217 & 33.018 & 967.2 \\
\hline
\end{tabular}

"Abstracted, by permission, from "Thermodynamic Properties of Steam" by J. H. Keenan and F G Keyes, published by John Wiley \& Sons, Ine. 
23. Correction factor for standard conditions. - The correction factor for converting the capacity during test conditions to the capacity at standard conditions shall be determined by the formula:

$$
C_{s}=\left[\frac{215-65}{t_{s}-t_{l}}\right]^{1.5}=\left[\frac{150}{t_{\delta}-t_{l}}\right]^{1.5},
$$

where

$C_{s}=$ Correction factor

$t_{s}=$ Saturated-steam temperature during the test, ${ }^{\circ} \mathrm{F}$

$t_{l}=$ Average inlet-air temperature during test, ${ }^{\circ} \mathrm{F}$.

For convenience, these correction factors are given in table 2 for the range of temperature differences permitted by this standard.

$$
C_{s}=\left[\frac{150}{t_{s}-t_{l}}\right]^{1.5} . \quad \text { Range }\left\{\begin{array}{l}
t_{l}: 60.0^{\circ} \text { to } 75.0^{\circ} \mathrm{F} . \\
t_{s}: 214.0^{\circ} \text { to } 217.0^{\circ} \mathrm{F} .
\end{array}\right.
$$

TABLE 2.-Correction factors

\begin{tabular}{|c|c|c|c|}
\hline$t_{s}-t l$ & \multicolumn{1}{c|}{$C_{s}$} & $t_{s}-t_{l}$ & \multicolumn{1}{c|}{$C_{s}$} \\
\hline 157.0 & 0.9339 & 147.5 & 1.0254 \\
156.5 & .9383 & 147.0 & 1.0307 \\
156.0 & .9428 & 146.5 & 1.0361 \\
155.5 & .9473 & 146.0 & 1.0414 \\
155.0 & .9518 & 145.5 & 1.0467 \\
154.5 & .9567 & 145.0 & 1.0522 \\
154.0 & .9612 & 144.5 & 1.0577 \\
153.5 & .9660 & 144.0 & 1.0632 \\
153.0 & .9708 & 143.5 & 1.0687 \\
152.5 & .9754 & 143.0 & 1.0744 \\
152.0 & .9802 & 142.5 & 1.0800 \\
151.5 & .9852 & 142.0 & 1.0856 \\
151.0 & .9901 & 141.5 & 1.0915 \\
150.5 & .9951 & 141.0 & 1.0973 \\
150.0 & 1.0000 & 140.5 & 1.1031 \\
149.5 & 1.0049 & 140.0 & 1.1091 \\
149.0 & 1.0100 & 139.5 & 1.1152 \\
148.5 & 1.0152 & 139.0 & 1.1210 \\
148.0 & 1.0204 & & \\
\hline
\end{tabular}

24. Condensation capacity under standard conditions:-The condensation capacity under standard conditions $\left(H_{s}\right)$ shall be determined as follows:

$$
H_{s}=C_{s} \times H_{1 s}
$$

25. Sources of error in steam convector testing. - The major sources of error are as follows:

(a) Entrained water brought into the convector with the steam.

(b) Improper measuring of condensate caused by heat loss of supply and condensate piping.

(c) Loss of condensate during the process of collecting by spillage or evaporation.

(d) Incomplete venting of the convector.

(e) Excessive air currents inside test room or hooth due to disturbances.

(f) Wet or insufficient insulation on piping. 
(g) Incorrect calibration of thermometers and scales.

(h) Starting test before equilibrium is obtained.

(i) Inaccurate inlet air temperature readings due to improper shielding.

\section{METHODS OF TESTING HOT-WATER CONVECTORS}

\section{Test conditions.}

26a. Relative humidity and air motion.--It is inadvisable for relative humidity in the test room or booth at the time of test to exceed 75 percent. Air motion shall be limited to natural circulation.

26b. Air temperature.-The convector shall be tested with an inlet air temperature of not less than $60^{\circ} \mathrm{F}$ nor more than $75^{\circ} \mathrm{F}$. This temperature shall be measured at three or more points spaced not more than 8 inches apart throughout the length of the inlet-air opening midway between the top and bottom and 18 inches in front of the inlet. The outer thermometers shall be not more than 3 inches from the ends of the air inlet. The last 2 inches of the temperature sensitive end, if more than 0.03 inch in diameter, shall be shielded against radiation by bright-metal shields of such construction as not to interfere with the air flow. (See fig. 2 for suggested construction.) The thermometer used in the test shall be accurate within $1 / 2 \mathrm{deg} F$. The sensitive end of the thermometer shall be not more than $5 / 16$ inch in diameter. It is recommended that temperature readings be taken in the center of the room or booth at levels of 3 inches, 30 inches, and 60 inches above the floor and 3 inches below the ceiling.

26c. Water supply.

(1) During the test the hot water shall be supplied to the convector at a rate not varying more than 2 percent, and the water temperature shall not vary more than 1 deg $F$.

(2) The temperature of the water entering and leaving the convector shall be measured by thermometers in direct contact with the water. These thermometers shall be accurate to $1 / 4$ deg $\mathrm{F}$ and shall be located within 3 feet of the convector. The piping between the convector and these thermometers shall have an external surface not to exceed 3 percent of the convector heating surface and shall be insulated with equivalent to 1-inch hairfelt or better. (Fig. 3 illustrates a suitable method of water supply.)

(3) It is very important that the water in the inlet and outlet supply piping be thoroughly mixed at the point of temperature measurement to avoid errors due to stratification.

26d. Air venting.-The convector shall be vented before starting the test by means of a manually operated air vent through the regular opening provided.

27. Test procedure.

27a. Start of test. - The test shall be started after a state of equilibrium has been reached. Such a state of equilibrium may be considered as obtained if the inlet air temperature has not varied more than $1 \mathrm{deg} F$ and the water temperature not more than $1 \mathrm{deg} F$ for a period of 30 minutes, and the rate of water flow has not varied more than 2 percent. 
27b. Duration of test.-A test shall be conducted for not less than 10 minutes. At least two such tests shall be made consecutively. The water heat capacity determined by these tests corrected to standard conditions shall not vary more than 3 percent.

27c. Readings.

(1) The total water flow during the test periods shall be collected and weighed to an accuracy of at least $1 / 2$ percent.

(2) The inlet air temperatures shall be read at least at the beginning and at the end of each test. Intermediate readings may be taken. The average of the air-temperature readings taken at the beginning of the tests shall not vary more than 1 deg $\mathrm{F}$ from the average temperature readings taken at the end of the tests. The average of all the air temperatures shall be used for calculation.

(3) The water temperatures shall be read at the beginning and end of each test and during the test at intervals of not more than 2 minutes. These readings shall not vary more than $1 \mathrm{deg} \mathrm{F}$. The average of these temperatures shall be used for calculation.

28. Calculation of water heat capacity.-The water heat capacity of the convector under test conditions shall be determined by the formula

$$
H=W\left(\theta_{1}-\theta_{2}\right),
$$

where

$H=$ Water heat capacity for test conditions, Btu per hour

$W=$ Weight of water, pounds per hour

$\theta_{1}=$ Average entering water temperature, ${ }^{\circ} \mathrm{F}$

$\theta_{2}=$ Average leaving water temperature, ${ }^{\circ} \mathrm{F}$.

29. Correction for standard conditions.-Plot a performance curve on which the abscissa shows the difference between average water temperature and average inlet air temperature and the ordinate shows test heat capacities $(H)$, Btu per hour. From the values of average water temperatures used in the published ratings, deduct $65^{\circ} \mathrm{F}$ and for these differences, as abscissa values on the chart, read the Btu per hour from the curve. The values so obtained are the water heat capacities for standard air conditions $\left(65^{\circ} \mathrm{F}\right)$ and for the selected average water temperatures.

30. Sources of error in hot water convector testing.- The major sources of error are as follows:

(a) Incomplete venting of the convector

(b) Excessive air currents inside test room or booth due to disturbances

(c) Wet or insufficient insulation on piping

(d) Incorrect calibration of thermometers and scales

(e) Starting test before equilibrium is obtained

(f) Inaccurate water temperature readings due to stratification

(g) Inaccurate inlet air temperature readings due to improper shielding.

31. Water friction head.-Tests to determine the friction head through the convector may be made with water of room temperature. The connecting pipes shall be the same size as the convector tapping. Tests shall be made for the conditions prescribed in item 14 on form C-7. Figure 4 
shows suggested apparatus for making this test for hot-water convectors. Figure 5 shows the type of piezometer that may be used in connection with the test setup given in figure 4.

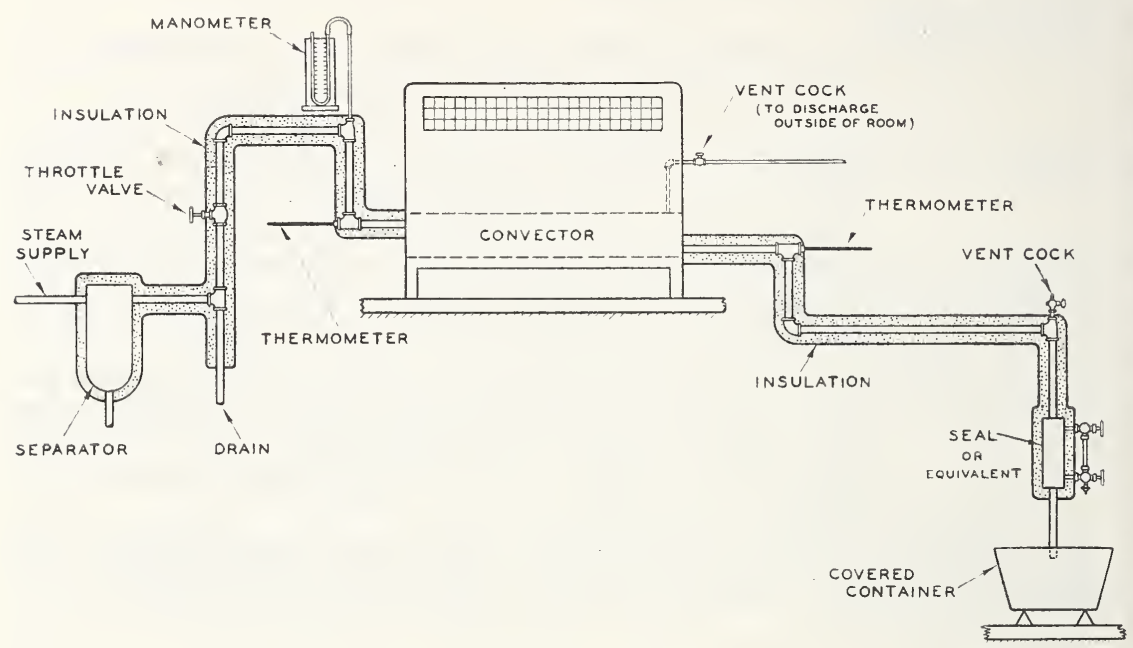

FigURE 1.-Suggested connections and equipment for supplying steam to the convector and measuring the condensate.

To simplify illustration, this diagram shows all apparatus in a single plane. It is essential that steam separator and seal be located immediately outside of test booth with as short intervening piping as possible.

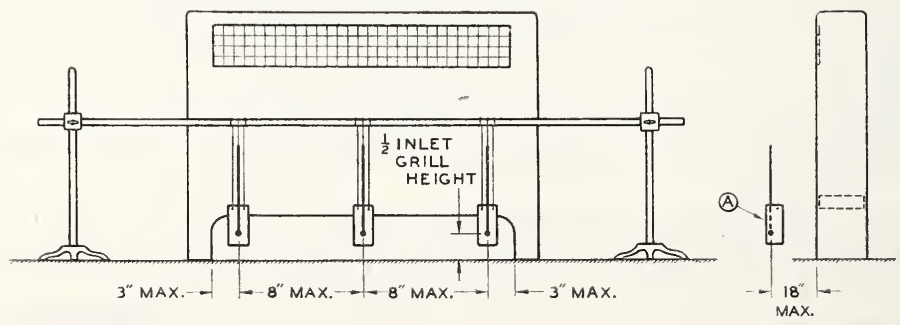

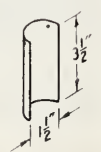

(A)

THERMOMETER SHIELD OF BRIGHT METAL

FIGURE 2.-Locations of thermometers for measuring inlet air temperatures. 


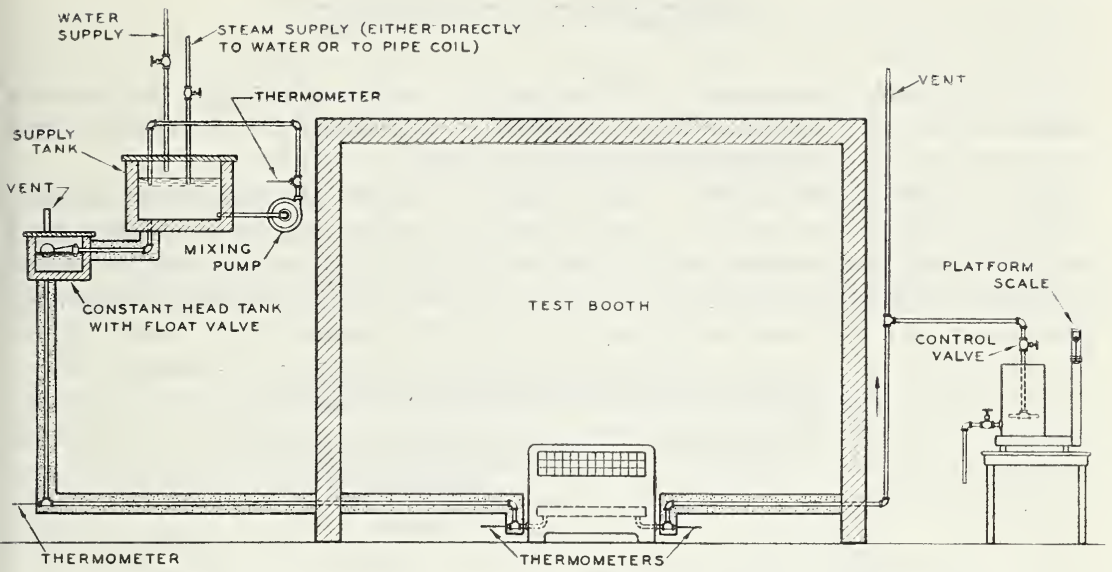

FIGURE 3.-Suggested method for testing heat emission of hot water conrectors.
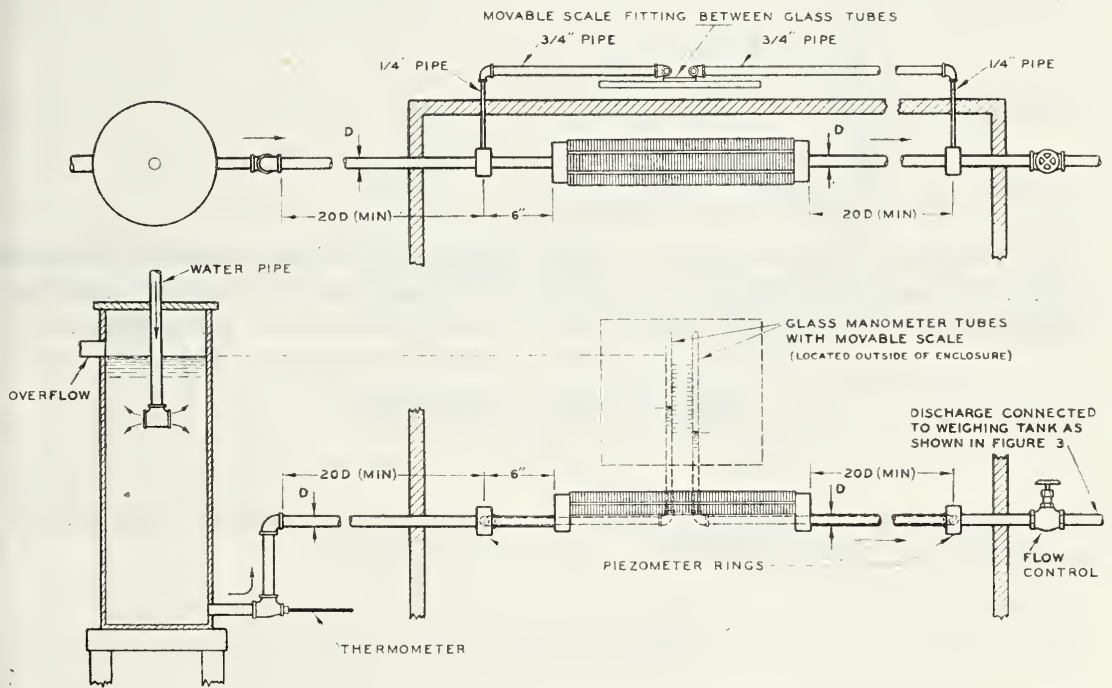

Figure 4.-Suggested methor for testing friction through hot water concector element.

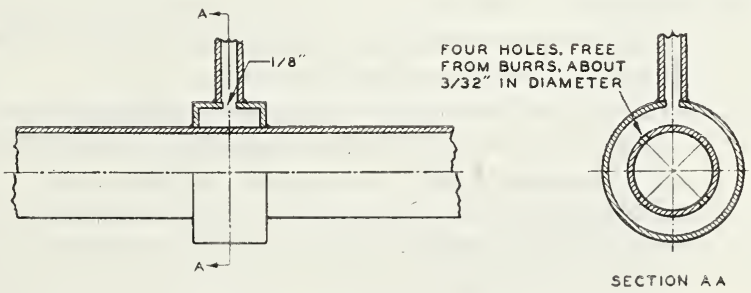

Figure 5.-Detail of piezometer rings shown in figure 4. 


\section{METHODS OF RATING}

32. Top outlet convectors. - The ratings of convectors with top outlets shall not exceed the capacity, as defined in paragraph 10 , or determined as prescribed in paragraphs $35,35 \mathrm{a}$, and $35 \mathrm{~b}$.

33. Front outlet convectors.-The ratings of convectors with front outlets shall not exceed the capacity, as defined in paragraph 10 , or determined as prescribed in paragraphs $35,35 \mathrm{a}$, and $35 \mathrm{~b}$, plus the percentages listed in table 3 . The percentages for sizes not listed in table 3 shall be interpolated from the two nearest figures given in the table.

TABLE 3.-Maximum additions to capacity

\begin{tabular}{|c|c|}
\hline $\begin{array}{c}\text { Over-all enclosure } \\
\text { height }\end{array}$ & $\begin{array}{c}\text { Add to capacity percentages not } \\
\text { exceeding those listed below to } \\
\text { arrive at rating }\end{array}$ \\
\hline 38 or more... & $\begin{array}{c}\text { Percent } \\
36\end{array}$ \\
34 & 1 \\
32 & 2 \\
$31 \ldots$ & 3 \\
$30 \ldots$ & 4 \\
29 & 5 \\
27 & 6 \\
26 & 7 \\
24 & 8 \\
$23 \ldots$ & 9 \\
22 & 10 \\
$21 \ldots \ldots$ & 11 \\
\hline
\end{tabular}

34. Inclined outlet convectors. - The ratings of inclined outlet convectors shall not exceed the capacity as defined in paragraph 10 or determined as prescribed in paragraph 36 , plus the percentages in table 3 multiplied by

\section{$\frac{\text { Angle of outlet to horizontal }}{90}$.}

For example, a $45^{\circ}$ inclined outlet of an enclosure 25 inches high allows an addition to the capacity of

$$
\frac{45}{90} \times 10=5 \text { percent }
$$

35. C'apacities of untested sizes.

35a. Steam convectors.

(1) Capacities of convectors with untested enclosure heights shall be determined by lineal interpolation between tested heights. (See paragraph 15.)

(2) Capacities of convectors of untested lengths shall be determined by multiplying the capacity of the tested convector of the same type and depth by the ratio obtained by dividing the heating surface of the untested convector by the heating surface of the tested convector. The heating surface shall include all convector primary and secondary heating surface exposed to circulating air, including sur- 
face of the headers. This extension of the test results is only permissible if for all lengths, the enclosure depth, the stack height, and opening heights and widths are the same; also, if the length of inlet and outlet grilles or openings and free area are changed in the abovementioned ratio. (See paragraph 38 .)

35b. Hot-water convectors.-If the water convector is similar to the steam convector (as defined in paragraph 17e), the relation between capacities of tested and untested sizes of the water convector shall be identical to the relation between the capacities of the corresponding sizes of the steam convector.

36. Capacities of untested inclined outlet convectors. - The capacity of a convector with inclined outlet enclosure where the inclined outlet has an inclination of $60^{\circ}$ or less from the horizontal shall be the same as an identical convector which has been tested with top outlet enclosure, the height of which is equal to the distance from the center of the inclined outlet to the bottom of the enclosure.

37. Reduction in ratings for variations in enclosure material.-The material of enclosure ends and back may be different from those used during the test. If a metal front panel was used during the test and is replaced by a nonmetallic panel, the rating shall be reduced 5 percent.

38. Reductions in ratings for dimensional variations.

38a. Where inside enclosure depth does not exceed depth of test enclosure by more than 2 percent, no reduction. For each additional 1 percent depth, deduct 2 percent.

$38 \mathrm{~b}$. Where stack height is lower than stack height used during test by 3 percent or less, no reduction. For each additional 1 percent reduction in stack height, deduct $1 / 2$ percent.

38c. Where inside enclosure length does not exceed length of enclosure used during test by more than 2 percent, no reduction. For each additional 1 percent increase in length, deduct 1 percent.

$38 \mathrm{~d}$. Where any opening height or width or the free area is less than that used during test by 10 percent or less, no reduction. For each additional 1 percent reduction in any opening height or width or the free area, deduct 1 percent.

\section{LABELING AND APPROVALS}

39. The procedure outlined below will become available to all manufacturers, whether members of the sponsor Associations or not, in connection with approval of convector ratings.

40. Compliance.- In order that the purchaser may be assured of obtaining convectors rated according to this standard, manufacturers may, individually or in concert with their trade association, declare that the ratings of convectors have been determined in conformity with this standard. Manufacturers whose convectors are rated in conformity with the provisions of this standard and whose ratings have been approved as prescribed in paragraphs $41 \mathrm{a}$ and $41 \mathrm{~b}$ may include in their sales literature an 1 on invoices and contracts the following statement:

The ratings of these convectors have been determined in conformance with Commercial Standard CS140-47, as developed cooperatively by the trade and the National Bureau of Standards, U. S. Department of Commerce, and the said ratings have been approved by the Convector Rating Commititee. 
41. Approval of ralings.

41a. In order that convectors may be purchased with full confidence that the ratings used by the manufacturer have been determined strictly in accordance with Commercial Standard CS140-47, the manufacturers who are members of The Institute of Boiler and Radiator Manufacturers and of the Convector Manufacturers Association, respectively, have appointed two of three members of a Convector Rating Committee with authority to receive and analyze test data which the manufacturer has used in determining his convector ratings. The third member has been appointed by the Division of Trade Standards, National Bureau of Standards. The Division of Trade Standards, National Bureau of Standards, has appointed a secretary of the Convector Rating Committee, to whom manufacturers who desire approval of ratings will submit their test data and requested ratings. The secretary will be responsible for referring said data to the Convector Rating Committee and receiving from that committee their determinations as to whether the ratings requested by the manufacturer represent accurate results based on the provisions of this commercial standard.

41b. The use of the compliance statement covered in paragraph 40 may be construed as evidence that said committee has approved the ratings used by the manufacturer. Approval of the committee will be furnished to the manufacturer in writing, signed by the secretary of the committee.

42. Data required for approval.-Parts 1, 2, 3 and 4 set forth in detail the conditions to be observed in determining convector ratings. Tests may be conducted by the manufacturer or at any laboratory selected by him, but all the observations taken and the results obtained during the test period are to be recorded and submitted on forms prescribed below, which will be provided at cost by the secretary of the committee upon request.

42a. Test reports.

(1) Forms C-6 and C-7 are to be used for reporting test results on steam and water convectors, respectively. The data on these forms are to be recorded from individual manufacturer's log sheets, and the signature of the manufacturel will be construed as a certification that the data reported on these forms accurately represent the results obtained on tests conducted according to the provisions and within the limitations of this standard.

(2) On steam tests, Form C-6 shall be filed covering, on one sheet, the various tested enclosure heights for a given "Type and Nominal Depth." Each "Type and Nominal Depth" is to be reported on a separate sheet.

(3) On water tests, Form C-7 shall be filed for the "Type and Nominal Depth" of a convector of the over-all enclosure height used in test. Separate sheets are to be filed covering each convector type and depth and for each style and enclosure tested. Graphs are to accompany each copy of Form C-7 that is submitted, in accordance with the provisions of paragraph 29.

42b. Dimensional data reports.-Forms C-3, C-4, and C-5 are to be submitted for each cataloged convector and enclosure. Separate sheets 
of these forms are to be submitted if the dimensions of steam and water convectors differ.

42c. Request for approval of ratings.

(1) Forms $\mathrm{C}-1$ and $\mathrm{C}-2$ constitute official request from the manufacturer to the committee for approval of ratings that are to be included in trade literature, and shall be filed IN DUPLICATE.

(2) One form C-1 only need be used to cover steam and hotwater ratings if the steam and water convectors are similar in all respects as defined in paragraph $17 \mathrm{e}$. If steam and water convectors differ, separate copies of form $\mathrm{C}-1$ must be filed covering steam and water ratings, respectively.

(3) Form $\mathrm{C}-2$ is to be used only where water heat ratings are expressed in trade literature in Btu per square foot of catalog steam rating and where steam and water convectors are similar in all respects as defined in paragraph $17 \mathrm{e}$.

43. Use of approved ratings. - Receipt by the manufacturer of copies of forms $\mathrm{C}-1$ and $\mathrm{C}-2$ signed by the secretary of the committee will constitute official approval for the use of those ratings, and thereafter no ratings for those convectors in excess of the approved ratings shall be used by the manufacturer. Two copies of trade literature incorporating these ratings shall be filed by the manufacturer with the secretary of the committee as soon as available. The manufacturers' trade literature shall state the percentages which have been added to condensation capacity or water heat capacity in determining catalog ratings of front outlet and inclined outlet enclosures. This statement shall be printed adjacent to the catalog ratings, substantially as follows:

These ratings represent the condensation capacity (or water heat capacity) to which have been added the following percentages in accordance with the provisions of Commercial Standard CS140-47. 
Secretary, Convector Rating Committee, Room 1001, 60 East Forty-Second Street, New York 17, N. Y.

\section{REQUEST FOR APPROVAL OF RATINGS (Square Feet)}

(Form C-1)

NoTE.-This form is to be used for both steam and hot water ratings and only one form need be used if steam and water convectors are similar in all respects as defined in paragraph $17 \mathrm{e}$ of the commercial standard. If steam and water convectors differ, use separate sheets and cross out "steam" or "water" after the name of the convector. Water ratings shall be based on $170^{\circ} \mathrm{F}$ average water temperature with $20^{\circ}$ drop through the convector.

$$
\text { Convector }\left\{\begin{array}{l}
\text { Steam. } \\
\text { Water. }
\end{array}\right.
$$

Physical dimensions shown on forms 3, 4, and 5, dated......................... Test results shown on forms..................... dated ........................

\section{RATINGS, SQUARE FEET}

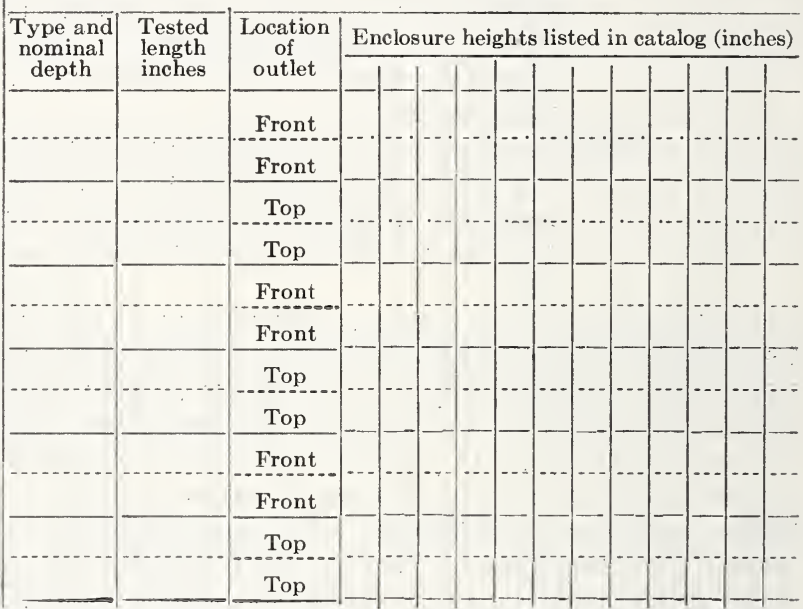

Approval of catalog ratings listed above is requested. The ratings of these convector types for lengths and enclosures not shown herein shall be based on the applicable paragraphs of the commercial standard. The undersigned manufacturer has determined that on all lengths and depths of these convectors the heating surface is adequately heated with reasonable pressure drops of the heating medium.

Manufacturer

$$
\text { By }
$$
Title.

Date..................................... 
Secretary, Conveotor Rating Committee, Room 1001, 60 East Forty-Second Street,

New.York 17, N. Y.

(Form C-2)

\section{REQUEST FOR APPROVAL OF WATER -RATINGS (Btu per Square Foot)}

Nore. - This form is to be used for hot water convectors where water heat ratings are expressed in trade literature in Btu per $\mathrm{sq} \mathrm{ft}$ of cataloged steam ratings and where the steam and water convectors are similar in all respects as defined in part one, paragraph $17 \mathrm{e}$ of the commercial standard.

Convector: Name

Type and nominal depth

Tested in enclosure of ...........inches over-all height with

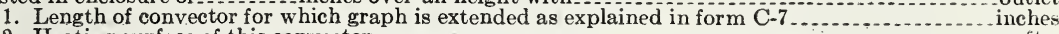

2. Heating surface of this convector

3. Heating surface of steam convector of same type and length

4. Length of steam convector tested in same height and style enclosure .____ inches

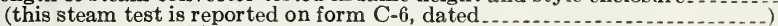

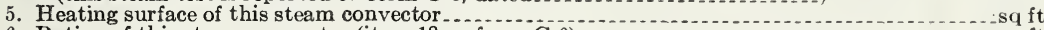

6. Rating of this steam convector (item 18 on form $\mathrm{C}-6)$

7. Rating of steam convector of same length as water convector (item $6 \times \frac{\text { item } 3}{\text { item } 5}$ ) ...............

8. Published average water temperature, ${ }^{\circ} \mathrm{F}$ (list all cataloged water temperatures)

9. Corresponding average water-air temperature, ${ }^{\circ} \mathrm{F}$ (item $8-65^{\circ} \mathrm{F}$ )

10. Water heat capacity, Btu/hr (read from graph

(item 1) for each temperature shown in item 9).

11. Rating, Btu/hr (item $10+$ percentage covered in paragraph 33 or 34 )

12. Rating per square foot steam rating,

$\mathrm{Btu} / \mathrm{sq} \mathrm{ft}$
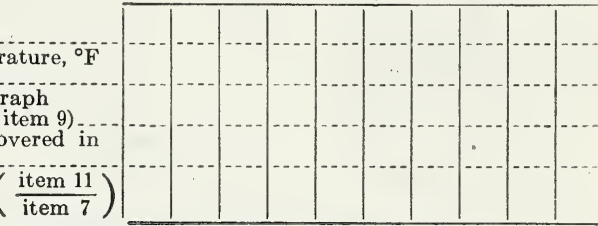

Approval is requested of ratings shown in item 12 for the temperature shown in item 8 . Our

steam and water convectors are similarin all respects as defined in paragraph $17 \mathrm{e}$ of the commercial standard These water ratings will be applied for all sizes of this convector to the steam ratings on form $\mathrm{C}-1$, dated

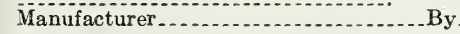

Title

Date....................................

The ratings listed above are hereby approved.

Date

Secretary, Convector Rating Committee

Secretary, Convector Rating Committee, Room 1001, 60 East For ty-Second Street,

New York 17, N. Y.

(Form C-3)

\section{DESCRIPTION OF.}

..CONVECTOR AND ENCLOSURE

NотE.-If physical dimensions listed herein apply only to steam or water convector, state which ...........

\section{Construction of heating el ment}

State whether assembled or one piece

If one piece, state material

If assembled, state: Material of headers

Material of tubes

Details of convector

Material of fins

Nots.-The following details of convector are to be filled in only if fins and tubes are assembled.

Method of bonding.

Type.

Number of tubes

Size and thickness of fins

No. of fins per inch

No. of finz of tested length

Are inserts used in tubes?

Describe inserts

\begin{tabular}{|l|l|l|l|}
\hline &
\end{tabular}

(n)

\section{Enclosure}

Material of back, top and sides

Material of front

Remarks

1.

Manufacturer

By

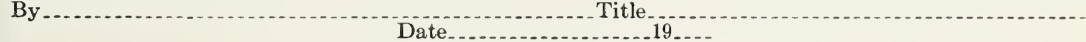


Secretary, Convetor Rating Committee, Room 1001, 60 East Förty-Second Street, New York 17, N. Y.

PHYSICAL DIMENSIONS OF CONVECTOR
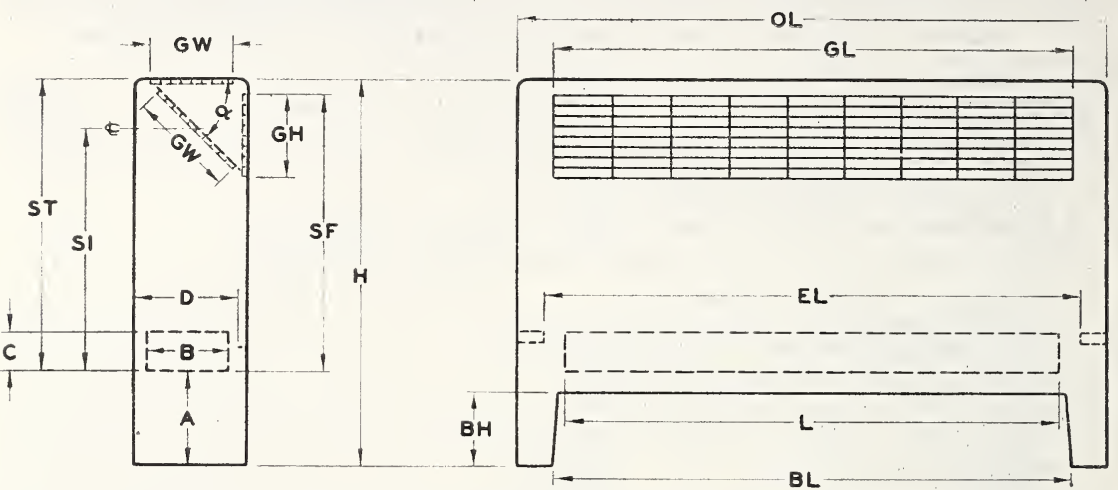

Note,-If physical dimensions listed herein apply only to steam or water eonvector, state which.

CONVECTOR DIMENSIONS

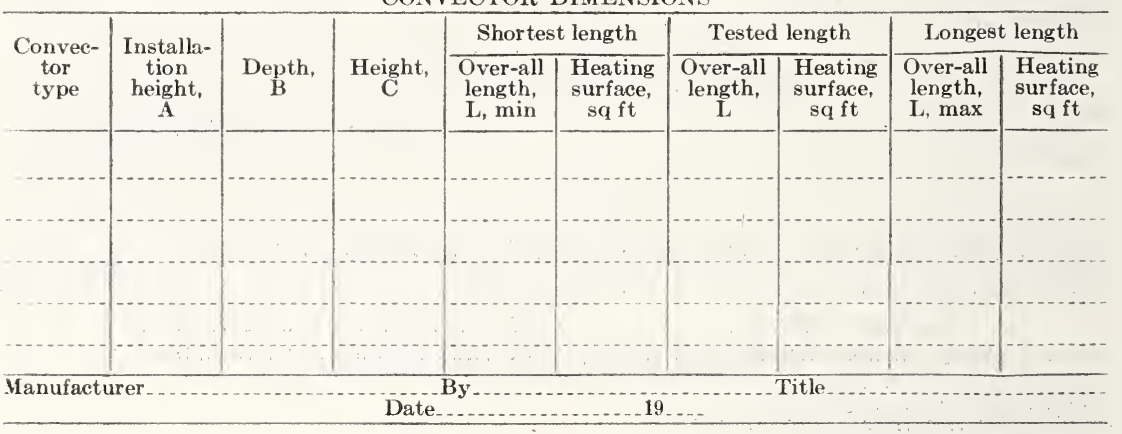


Secretary, Convector Rating Committee, Room 1001, 60 East Forty-Second Street; New York $17, \mathrm{~N}, \mathrm{Y}$.

(Form C-5)

PHXSICAL DIMENSIONS OF ENCLOSURE FOR PKXSICAL DIMENSTONS ON ENCLOSURE FOR . ........................ CONVECTOR state which.

2. For key to symbols, see diagrams on form $\mathrm{C}-4$.

3. Express dimensions marked * as convector length + ENCLOSURE DIMENSIONS

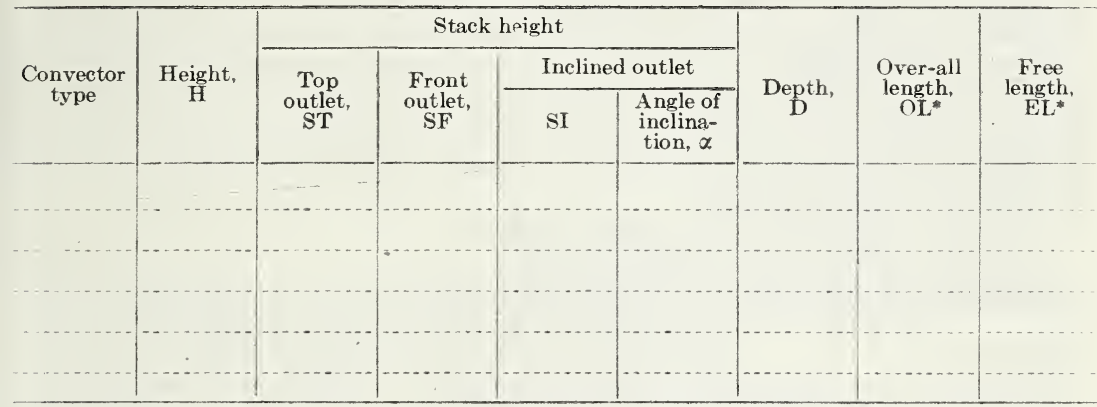

ENCLOSURE DIMENSIONS-Continued

\begin{tabular}{|c|c|c|c|c|c|c|c|c|}
\hline \multirow[b]{2}{*}{$\begin{array}{c}\text { Convector } \\
\text { type }\end{array}$} & \multirow[b]{2}{*}{$\begin{array}{l}\text { Height, } \\
\text { H }\end{array}$} & \multicolumn{3}{|c|}{ Inlet grille } & \multicolumn{4}{|c|}{ Outlet grille } \\
\hline & & $\begin{array}{c}\text { Height, } \\
\text { BH }\end{array}$ & $\begin{array}{l}\text { Length, } \\
\text { BL. }\end{array}$ & $\begin{array}{c}\text { Free area, } \\
\%\end{array}$ & $\begin{array}{l}\text { Height, } \\
\text { GH }\end{array}$ & $\begin{array}{l}\text { Width, } \\
\text { GW }\end{array}$ & $\begin{array}{l}\text { Length, } \\
\text { GL }^{*}\end{array}$ & $\begin{array}{c}\text { Free area, } \\
\%\end{array}$ \\
\hline & & & & & & & & \\
\hline & & & & & & & & - \\
\hline & & & & & & & & \\
\hline & & & & & & & & \\
\hline & & & & & & & & \\
\hline
\end{tabular}


Secretary, Convector Rating Committee, Room 1001, 60 East For ty-Second Street, New York 17, N. Y.

\section{CONVECTOR TEST REPORT (STEAM)}

NOTE-This form is to be used for reporting tests on steam convectors only.

Convector: Name ................ Type and nominal depth.

1. Tested enclosure height, inches

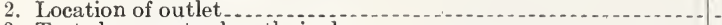

3. Tested convector length, inches

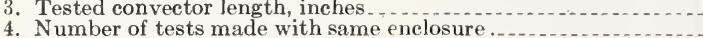

6. Steam inlet temperature, ${ }^{\circ} \mathrm{F}$

7. Steam pressure (1b absolute)

8. Steam temperature corresponding to pressure, ${ }^{\circ} \mathrm{F}$

9. Inlet air temperature, ${ }^{\circ} \mathrm{F}$

10. Steam temperature-inlet air temperature (item 8 - item 9

11. Duration of test, hr.

12. Total weight of condensate during test, lb.

13. Condensation rate, lb per hr (item 12 / item 11) -

14. Latent heat of steam $\left(\mathrm{H}_{\mathrm{fg}}\right), \mathrm{Btu} / \mathrm{lb}$

15. Condensation capacity at test, Btu/hr (item 14 Xitem 13 .

16. Condensation capacity for standard conditions, Btu/hr (part two, paragraph 24 of the commercial standard)

17. Condensation capacity for standard conditions, sq ft (item $16 / 240$ )

18. Rating, sq ft (item $17+$ percentage covered in paragraph 33 or 34 ) Note.--Items 6 to 14 inclusive should represent average of tests conducted.

Manufacturer

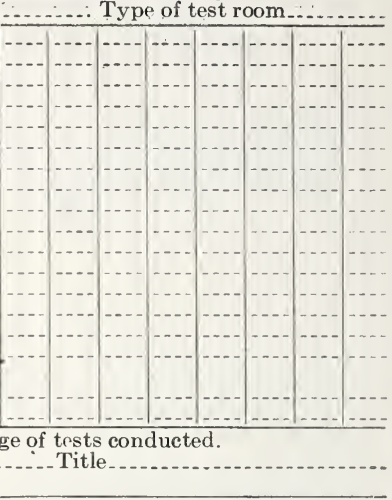

Secretary, Convector Rating Committee, Room 1001, 60 East Forty-Second Street,

New York 17, N. Y.

\section{CONVECTOR TEST REPORT (WATER)}

(Form C-7)

NoTE.-This form is to be used for reporting tests on water convectors only. Separate reports must be filed for each convector type and depth and for each style and height of enclosure tested.

Convector: Name........................ Type and nominal depth

Tested in enclosure of ....... inches over-all height with ....... outlet; inlet and outlet pipe size........ in.

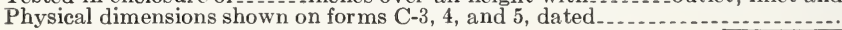

1. Intended nominal temperature drop through convector, ${ }^{\circ} \mathrm{F}$

2. Tested convector length, inches

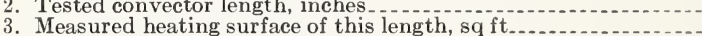

4. Number of tests made with same water temperature.

5. Average inlet water temperature, ${ }^{\circ} \mathrm{F}$

6. Average outlet water temperature, ${ }^{\circ} \mathrm{F}$

7. Average water temperature ${ }^{\circ} \mathrm{F}\left(\frac{\text { item } 5+\text { item } 6}{2}\right)$

8. Water temperature drop, ${ }^{\circ} \mathrm{F}$ (item 5 -item 6 )

9. Water flow, lb/hr

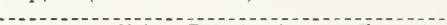

10. Water heat capacity at test condition, Btu/hr (item $8 \times$ item 9$)$...

11. A verage inlet air temperature, ${ }^{\circ} \mathrm{F} . .$.

12. Average water - inlet air temperature, ${ }^{\circ} \mathrm{F}$ (item 7 -item 11)

13. Plot for each intended temperature drop items 10 and 12 on a curve in accordance with paragraph 29 of commercial standard. If convector length used with high water temperatures differs from length used with low temperatures, plot each separately. Extend curve of shor t convector into untested temperature range by multiplying capacities read from curve of long convector by the ratio: heating surface of short convector heating surface of long convector

14. Resistance in inches water of longest convector for

flow rate required at a rating for $170^{\circ} \mathrm{F}$ average water temperature in 26 in. high enclosure with top outlet.

Fill in items below only wher separate water rating tables are published independent of steam rating tables

15. Water-heat capacity of ............ in. long convector for $170^{\circ} \mathrm{F}$ average water temperature and $20^{\circ} \mathrm{F}$ temperature drop (read from graph)

16. Percentage added for heating effect for enclosure height and ty pe shown above. (See paragraph 33 or 34 )

17. Rating, Btu/hr (item 15 toddition for heating effect shown as a percentage in item 16)

18. Rating, sq ft (item $17 \div 150)$ Manufacturer Date.................. 


\section{EFFECTIVE DATE}

44. The standard is effective for new production from March 1, 1948.

\section{STANDING COMMITTEE}

45. The following individuals comprise the membership of the standing committee, which is to review, prior to circulation for acceptance, revisions proposed to keep the standard abreast of progress. Comment concerning the standard and suggestions for revision may be addressed to any member of the committee or to the Division of Trade Standards, National Bureau of Standards, which acts as secretary for the standing committee.

\section{R. N. Trane, Chairman}

Manufacturers:

E. L. Broderick, American Radiator \& Standard Sanitary Corp., 675 Bronx River Road, Yonkers 4, N. Y.

A. G. Dixon, Modine Manufacturing Co., Racine, Wis.

R. E. Ferry, The Institute of Boiler \& Radiator Manufacturers, 60 East 42d St. New York 17, N. Y.

L. N. Hunter, The National Radiator Co., Johnstown, Pa.

John W. McElgin, J. J. Nesbitt Co., Holmesburg, Philadelphia, Pa. (Representing the Convector Manufacturers Association.)

M. W. McRaE, Crane Co., 4100 South Kedzie Avenue, Chicago 5, Ill.

R. N. Trane, The Trane Co., La Crosse, Wis.

Distributors and Installers:

C. S. Rambo, The Central Supply Association, 228 North La Salle St., Chicago 1, Ill.

H. F. Weldin, 3101 Market St., Wilmington, Del. (Representing National Association of Master Plumbers of the U. S., Inc.)

J. H. ZINk, JR., Heat \& Power Corp., 424 East Saratoga St., Baltimore 2, Md. (Representing the Heating, Piping \& Air Conditioning Contractors National Association.)

Plumbing \& Heating Wholesalers of New England, Inc., 31 St. James Ave., Boston 16, Mass. (Invited to name a representative.)

Users:

Rhees Burket, 1223 Connecticut Ave., N. W., Washington, D. C. (Representing The American Institute of Architects.)

S. J. Fentiman, Veterans Administration, Washington 25, D. C.

R. K. Thulman, Federal Housing Administration, Washington 25, D. C.

Laboratories:

R. S. Dill, National Bureau of Standards, Washington 25, D. C.

W. S. H ARRIS, University of Illinois, Urbana, Ill.

\section{HISTORY OF PROJECT}

46. In May 1941 a conference of convector manufacturers, representatives of Government agencies and other organizations was sponsored by the Subcommittee on Heating and Ventilating, Central Housing Committee, FHA, for the purpose of determining a generally acceptable basis for the solution of problems involved in the testing and rating of convectors.

47. Subsequently, the Joint Convector Code Committee, consisting of representatives of the Convector Manufacturers Association and the Institute of Boiler and Radiator Manufacturers, assisted by advisory members of the committee, representing the National Bureau of Standards and the University of Illinois, developed a code for testing and rating convectors. 
48. Under date of December 9, 1944, the draft so developed was submitted by the Joint Convector Code Committee to the National Bureau of Standards with a request for cooperation in the establishment of a commercial standard.

49. After minor changes in the draft the Division of Trade Standards circulated, on March 15, 1945, copies of the proposed commercial standard to manufacturers and representative user, distributor, and testing organizations, and to government agencies for review and advance comment.

50. Following adjustment of the requirements to represent the composite views of all interested groups, the recommended standard was circulated on July 19, 1946 to the trade for written acceptance.

51. Upon receipt of official acceptances representing a satisfactory majority of the trade and in the absence of active, valid opposition from any quarter, announcement was issued on March 3, 1947, that the standard would become effective for new production from March 1, 1948.

52. In accordance with advices from the Joint Convector Code Committee, this standard lepresents only the first step in a general program. Convector ratings heretofore published by manufacturers, generally have consisted of a condensation or water heat capacity plus a heating effect valuation, intended to represent the relation between the useful output of a convector, in the comfort zone of a room, and the total input as measured by steam condensation or water heat capacity. Manufacturers, regarding heating effect as a justifiable part of convector rating, have not agreed on a method for evaluating its magnitude. The committee's ultimate task, therefore, is to formulate methods of test which will accurately measure the complete performance of convectors of any design in advance of installation. Development of this ultimate objective will require a longer period of investigation and research. In the interim, the committee has made available a method for rating convectors which takes into consideration the condensation or water heat capacity and an evaluation of heating effect, as shown in table 3 .

53. The following named individuals constituted the Joint Convector Code Committee:

Representing the Convector Manufacturers Association:

R. N. Trane (chairman), The Trane Co., La Crosse, Wis.

A. G. Dixon, Modine Mff. Co., Racine, Wis.

Representing the Institute of Boiler and Radiator Manufacturers:

L. N. Hunter, The National Radiator Co., Johnstown, Pa.

M. W. McRae, Crane Co., Chicago, Ill.

Advisory Members:

R. S. Dill, National Bureau of Standards, Washington, D. C.

M. K. Fahnestock, University of Illinois, Urbana, Ill.

Secretary:

R. E. FERRY, The Institute of Boiler and Radiator Manufacturers; 60 East FortySecond Street, New York 17, N. Y. 


\section{ACCEPTANCE OF COMMERCIAL STANDARD}

If acceptance has not previously been filed, this sheet properly filled in, signed, and returned will provide for the recording of your organization as an acceptor of this commercial standard.

\section{Date}

Division of Trade Standards, National Bureau of Standards, Washington 25, D. C.

Sirs :

We believe that the Commercial Standard CS140-47 constitutes a useful standard of practice, and we individually plan to utilize it as far as practicable in the

production $^{1} \quad$ distribution ${ }^{1} \quad$ purchase $^{1} \quad$ testing $^{1}$

of convectors.

We reserve the right to depart from it as we deem advisable.

We understand, of course, that only those articles which actually comply with the standard in all respects can be identified or labeled as conforming thereto.

Signature of authorized officer.

(In ink)

(Kindly typewrite or print the following lines)

Name and title of above officer

Organization

(Fill in exactly as it should be listed)

Street address

City, Zone, and State

${ }^{1}$ Underscore which one. Please see that separate acceptances are filed for all subsidiary companies and affiliates which should be listed separately as acceptors. In the case of related interests, trade associations trade papers, etc., desiring to rocord their general support the words "General Support" should be added after the signature. 


\section{TO THE ACCEPTOR}

The following statements answer the usual questions arising in connection with the acceptance and its significance:

1. Enforcement.-Commercial standards are commodity specifications voluntarily established by mutual consent of those concerned. They present a common basis of understanding between the producer, distributor, and consumer and should not be confused with any plan of governmental regulation or control. The United States Department of Commerce has no regulatory power in the enforcement of their provisions, but since they represent the will of the interested groups as a whole, their provisions through usage soon become established as trade customs, and are made effective through incorporation into sales contracts by means of labels, invoices and the like.

2. The acceptor's responsibility.-The purpose of commercial standards is to establish for specific commodities, nationally recognized grades or consumer criteria and the benefits therefrom will be measurable in direct proportion to their general recognition and actual use. Instances will occur when it may be necessary to deviate from the standard and the signing of an acceptance does not preclude such departures; however, such signature indicates an intention to follow the commercial standard where practicable, in the production, distribution, or consumption of the article in question.

3. The Department's responsibility.-The major function performed by the Department of Commerce in the voluntary establishment of commercial standards on a Nation-wide basis is fourfold: first, to act as an unbiased coordinator to bring all interested parties together for the mutually satisfactory adjustment of trade standards; second, to supply such assistance and advice as past experience with similar programs may suggest; third, to canvass and record the extent of acceptance and adherence to the standard on the part of producers, distributors, and users; and fourth, after acceptance, to publish and promulgate the standard for the information and guidance of buyers and sellers of the commodity.

4. Announcement and promulgation.-When the standard has been endorsed by a satisfactory majority of production or consumption in the absence of active, valid opposition, the success of the project is announced. If, however, in the opinion of the standing committee or the Department of Commerce, the support of any standard is inadequate, the right is reserved to withhold promulgation and publication. 


\section{ACCEPTORS}

54. The organizations listed below have individually accepted this Commercial Standard as their standard of practice in testing and rating convectors. Such endorsement does not signify that they may not find it necessary to deviate from the standard, nor that producers so listed guarantee all of their products in this field to conform with the requirements of this standard. Therefore, specific evidence of conformity should be obtained where required.

\section{ASSOCIATIONS \\ (General Support)}

American Association of Engineers, Chicago, Ill.

American Specification Institute, Chicago, Ill

British Columbia Research Council, Vancouver, B. C., Canada.

Convector Manufacturers Association, Chicago, Ill. Fuel Oil Distributers Association of New Jersey, Newark, N. J.

Heating, Piping \& Air Conditioning Contractors District of Columbia Association, Inc., Washington, D. C

Heating, Piping \& Air Conditioning Contractors National Association, New York, N. Y.

Institute of Boiler \& Radiator Manufacturers, The, New York, N.Y.

Oil-Heat Institute of America, Inc., New York, N. Y.

Sanitary Brass Institute, Pittsburgh, $\mathrm{Pa}$.

Western Plumbing Officials Association, Los Angeles, Calif.

\section{FIRMS}

Acme Electric Heating Co., Boston, Mass.

Adams, Franklin O., Tampa, Fla.

Ahern Co., John F., Fond du Lac, Wis.

Air Conditioning, Inc., Bethesda, Md.

Akron Plumbing \& Heating Co., Akron, Ohio.

Alcar Supply Co., Inc., Rochester, N. Y.

Allen Co., A. G., Indianapolis, Ind. (General upport.)

Armour Research Foundation, Chicago, Ill.

Automatic Heat, Inc., Philadelphia, Pa.

Automatic Heat \& Air Conditioning Corp., Joliet, Ill.

Baker, Smith \& Co., Inc., New York, N. Y.

Barber Co., Wm. C. Churchville, N. Y.

Baumer, Herbert, Columbus, Ohio.

Beggs Co., W. E., Seattle, Wash.

Belden Porter Co., Minneapolis, Minn.

Better Living Co., Jackson, Miss.

Beuttler, William, Sioux City, Iowa.

Biddell Co., Louisville, Ky.

Biddle Purchasing Co,, New York, N. Y.

Bjorkman Bros. Co., Minneapolis, Minn.

Bon Heating Co., Milwaukee, Wis.

Boyd Engineering Co., Albuquerque, N. Mex., and El Paso, Tex.

Braman, Dow \& Co., Boston, Mass.

Bridgeport Brass Co., Bridgeport, Conn. (General support.)

Brooks-Borg, Des Moines, Iowa.

Bucky, Fred W., Jr., Jacksonville, Fla.

Buerkel \& Co., Inc., Boston, Mass.

Bull, Ralph N., Sparta, N. J.

Burnham Boiler Corp., Irvington, N. Y.

Cagney Co., J. R., Chicago, Ill.

Campbell Heating Co., E. K., Kansas City, Mo.

Cannon \& Mullen, Salt Lake City, Utah.

Carnegie Institute of Technology, Pittsburgh, Pa (General support.)

Chapin, Rollin C., Minneapolis, Minn, (General support.)

Cincinnati, City of, Cincinnati, Ohio.

Clarke Bros., Indianapolis, Ind.

Colbert Co., Inc., Maurice J., Washington, D. C.

Conrad Bros., Chicago, Ill.

Conrad \& Cummings, Binghamton, N. Y.

Consolidated Heating \& Ventilating Co., Los Angeles, Calif.
Corriveaux, F.-Home \& Ind ustrial Service, Schenectady, N. Y.

Cram \& Ferguson, Boston, Mass.

Crane Co., Chicago, Ill.

Crosbie Co., The, Washington, D. C.

Curtsinger, L. P., Eugene, Oreg.

Dallman Supply Co., San Francisco, Calif.

Daly \& Sons, Inc., M. J., Waterbury, Conn.

Danforth Co., John W., Buffalo, N. Y.

Daniel-Morris Co., Inc., New York, N. Y.

Deane \& Harris Co., Detroit, Mich.

DeJarnette, Charles W., Des Moines, Iowa.

Detroit, University of, Detroit, Mich.

Dierks \& Co., Inc., A., Brooklyn, N. Y.

District Engineering Co., Washington, D. C.

Donovan, John J., Berkeley, Calif.

Dudley, James G., New York, N. Y.

Dunham Co., C. A.. Chicago, Ill.

Dunkirk Radiator Corp., Dunkirk, N. Y.

Edwards Heating Co., D. F., St. Louis, Mo.

Electrical Testing Laboratories, Inc., New York, N. Y.

Elliott-Lewis Co., Inc., Philadelphia, Pa.

Emery Industries, Inc., Cincinnati, Ohio.

Evans, Inc., John P., Washington, D. C.

Fargo Foundry Co., Fargo, N. Dak.

Fitzsimmons \& MeÄllister, Inc., Albany, N. Y.

Flannagan, Eric G., Henderson, N. C.

Geisler \& Co., F. E., Pittsburgh, Pa.

General Electric Co., Schenectady, N. Y.

Glauber, Inc., Sam S., New York, N. Y.

Graves Engineering Co., Nashville, Tenn. (General support.)

Graves \& Graves, Chicago, Ill.

Greene Co., C. W., Worcester, Mass.

Gregory Heating \& Plumbing Co., J. M., Jacksonville, Fla.

Guimarin \& Co., W. B., Columbia, S. C.

Hahn, Stanley W., Cleveland, Ohio.

Haldeman, Inc., Harry F., Los Angeles, Calif.

Hanley Co., S. V., Milwaukee, Wis.

Harley, Ellington \& Day, Inc., Detroit, Mich.

Harris, Jay, New York, N. Y.

Hasness, Carlisle D., Harrisburg, Pa.

Helfensteller, Hirsch \& Watson, St. Louis, Mo.

Hodgdon, Charles, San Gabriel, Calif.

Hope, Frank L., Jr., San Diego, Calif.

Hubbard, Lange \& Heck, Inc., New York, N. Y.

Hughes \& Co., Spokane, Wash.

Hughes Heating Co., Memphis, Tenn.

Ideal Furnace Co., Detroit, Mich.

International Heater Co., Utica, N. Y.

Iron Fireman Sales Corp., Washington, D. C.

Jacobs, Lionel L., Wayne, Pa. (General support.

Jaehnig \& Peoples, Inc., Newark, N. J.

Johnson, Larsen \& Co., Detroit, Mich.

Kahn, Albert, Associated Architects \& Engineers, Inc., Detroit, Mich.

Keich \& O'Brien, Warren, Ohio.

Ken neally Co., V. J., Boston, Mass.

Kiefer Plumbing Co., J. E., Denver, Colo.

Kilham, Hopkins \& Greeley, Boston, Mass.

Krauser-Boyd, Inc., North Tonawanda, N. Y.

Kyel, Herbert S., Charleston, W. Va. (General support.)

Larrick, Thomas, Athens, Ohio.

Latenser \& Sons, John, Omaha, Nebr.

Laver, Earl W.; Utica, N. Y.

Law, Law, Potter \& Nystrom, Madison, Wis. Leidy Electric Co., Inc., Phillipsburg, N. J. 
Lewiston Hardware \& Plumbing Supply Co., Raub Supply Co., Lancaster, Pa.

Lewiston, Maine.

little \& Son, C. J., Youngstown, Ohio.

Jochman Co., Edward W., Kansas City, Mo.

Loeb, Laurence M., White Plains, N. Y.

Lohman Bros., Los Augele's, Calif.

Iowry Electric Co., Inc., Williansport, Pat.

Iam \& Co., Hutchinson, Kans.

Martino Co., A. R., Waterbury, Comn.

Massena \& duPont, Wilmington, Del.

Master Plumber \& Heating Contractor, Brooklyn, N. Y. (General support.)

Maupai Co., Inc., R. G., Jersey City, N. J.

McCord Corp., Detroit, Mich.

McQuay, Inc., Minneapolis, Minn.

Mechanical Construction Corp., Hibbing, Minn.

Mehring \& Hanson Co., Washington, D. C.

Michigan State College, E. Lansing, Mich.

Mid-States Industrial Corp., Rockford, III.

Minneapolis, City of, Engineering Department, Minneapolis, Minn.

Minnesota, University of, Minneapolis, Minn.

Modine Manufacturing Co., Racine, Wis.

Monroe Air Conditioning Co., Inc., Rochester, N. Y

Montgomery Ward, Chicago, Ill.

Mooser, William, San Francisco, Calif.

Moran Plumbing \& Heating Service, Clifford, Highland Park, Ill.

Mueller Furnace Co., L. J., Milwaukee, Wis.

Mueller, Hair \& Hetterich, Hamilton Ohio.

I utual Heating \& Plumbing Co., Buffalo, N. Y.

National Radiator Co., The, Johnstown, Pa.

Nesbitt, Inc., John J., Holmesburg, Philadelphia, Pa.

Neuhaus Heating \& Ventilating Co., H. J., Chicago, IIl.

New York Testing Labor tories, Inc., New York, N. Y.

Noland Co., Inc. Newport News. Va

North Dakota Agricultural College, Fargo, N. Dak.

Northern Heating \& Plumbing Co., Inc., Laconia, N. H.

Northwestern Heating \& Plumbing Co., Evanston, Ill.

Officer, Gwynn, Lafayette, Calif.

Ohio Pipe \& Supply Co., Inc., Cleveland, Ohio.

Oklahoma, University of, Norman, Okla.

Orange Memorial Hospital, Orange, N. J. Oviatt Plumbing \& Heating Dist. Co., Inc., Troy,

Pacific Coast Heating \& Appliance Co., Portland, Oreg.

Pehrson \& Associates, G. A., Spokane, Wash.

Pennsylvania Engineering Co., Philadelphia, Pa.

Pennsylvania Hospital, Philadelphia, Pa.

Pepper, George W., Philadelphia, Pa.

Perfect Air Conditioning Co., Washington, D. C.

Prause, W. K., Charleston, S. C.

Premier Engineering Co., Inc., Chicago, Ill.

Rariden, Henry M., Bedford, Ind.

Rautman Plumbing \& Heating, Seattle, Wash.

Rearick Brothers Heating \& Supply Co., Gary, Ind.

Richmond Radiator Co., Uniontown, Pa.

Ritchie \& Associates, James H., Boston, Mass.

Rochester Fire College, Rochester, N. Y.

Rome Turney Radiator Co, Rome, N. Y. (General support.)

Royal Stean Heater Co., Gardner, Mass.

Sawyer Heating Co., Detroit, Mich.

Schulzke, William H., Moline, Ill.

Schuylkill Valley Oil Co., Pottstown, Pa.

Sears, Roebuck \& Co., Chicago, Ill.

Sheet Metal Products Co., Inc., Shamokin, Pa.

Sleeper, Harold R., New York, N. Y.

Slyder-Clough Heating Co., Inc., Washington, D. C.

Smith Co., Inc., The H. B., Westfield, Mass.

Smith, Hinchman \& Grylls, Detroit, Mich.

Specification Record, Chicago, Ill.

Sprinchorn \& Co., Jamestown, N. Y

Staub \& Rather, Houston, Tex.

Stoetzel, Ralph, Chicago, Ill.

Swarthmore Heating Service, Swarthmore, Pa.

Taylor, Ellery K., Haddonfield, N. J.

Temple, Seth J. \& Arthur, Davenport, Iowa.

Tennessee, University of, Engineering Experiment Station, Knoxville, Tenn.

Texas Technological College, Department of Agriculture \& Allied Arts, Lubbock, Tex. (General support.)

Tharp \& Son, Chas, E., Ft. Wayne, Ind.

Thorne, Henry Calder, Ithaca, N. Y.

Trane Co., The, La Crosse, Wis.

Tuttle \& Bailey, Inc., New Britain, Conn.

U. S. Supply Co., Kansas City, Mo.

United States Radiator Corp., Detroit, Mich.

United States Testing Co., Inc., Hoboken, N. J. (General support.)

Utica Radiator Corp., Utica, N. Y.

Viking Manufacturing Corp., The, Cleveland, Ohio.

Virginia Polytechnic Institute, Blacksburg, Va. (General support.)

Wahpeton Plumbing \& Heating Co., Wahpeton, N. Dak.

Webster \& Co., Warren, Camden, N. J.

Weil-McLain Co., Erie, Pa.

Weiss Heating \& Plumbing Co., The, Clevelund. Ohio.

Wiedebusch Plumbing \& Heating Co., Fairmont, W. Va.

Winter Co., G. C., Southbridge, Mass.

Young Radiator Co., Racine, Wis.

\section{UNITED STATES GOVERNMENT}

Agriculture, U. S. Department of, Washington, D. C

Federal Works Agency, Public Buildings Administration, Washington, D. C.

National Housing Agency, Federal Housing Admin-

istration, Washington, D. C.

War Department, Washington, D. C.

\section{COMMERCIAL STANDARDS}

CS No.

0 - Commercial standards and their value to business (third edition).

1-42. Clinical thermometers (third edition)

2-30. Mopsticks.

3-40. Stoddard solvent (third edition).

4-29. Staple porcelain (all-clay) plumbing fixtures.

5-46. Pipe nipples; brass, copper, steel and wrought-iron (second edition).

6-31. Wrought-iron pipe nipples (second edition). Superseded by CS5-46.

7-29 Standard weight malleable iron or steel screwed unions.

8-41. Gage blanks (third edition).

9-33. Builders' template hardware (second edition).

10-29. Brass pipe nipples. Superseded by CS546.

11-41. Hoisture regains of cotton yarns (second edition).

12-40. Fuel oils (fifth edition)
Item

CS No.

13-44. Dress patterns (fourth edition).

14-43. Boys' button-on waists, shirts, junior and sport shirts (made from woven fabrics) (third edition).

15-46. Men's pajamas (made from woven fabrics) (third edition).

16-29. Wall paper.

17-42. Diamond core drill fittings (third edition)

18-29. Hickory golf shafts.

19-32. Foundry patterns of wood (second edition)

20-42. Staple vitreous china plumbing fixtures (third edition).

21-39. Interchangeable ground-glass joints, stopcocks, and stoppers (fourth edition).

22-40. Builders' hardware (nontemplate) (second edition)

23-30. Feldspar.

24-43. Screw threads and tap-drill sizes.

25-30. Special screw threads. Superseded by CS24-43.

26-30. Aromatic red cedar eloset lining. 
S No.

27-36. Mirrors

8-46. Cotton (second edition)

ents, tarpaulins and covers (second edition).

29-31. Staple seats for water-closet bowls

$30-31$. Colors for sanitary ware.

31-38. Wood shingles (fourth edition).

$32-31$. Cotton cloth for rubber and pyroxylin coating.

33-43. Knit underwear (exclusive of rayou) (second edition)

34-31. Bag, case, and strap leather

35-47. Hardwood plywood (third edition)

36-33. Fourdrinier wire cloth (second edition).

37-31. Steel bone plates and screws.

38-32. Hospital rubber sheeting.

39-37. Wool and part wool blankets (second edition). (Withdrawn as commercial standard, July 14, 1941).

40-32. Surgeons' rubber gloves.

41-32. Surgeons' latex gloves.

42-43. Structural fiber insulating boasd (third edition).

43-32. Grading of sulphonated oils.

44-32. Apple wraps.

45-47. Douglas fir plywood (seventh edition)

46-40. Hosiery lengths and sizes (third edition)

47-34. Marking of gold-filled and rolled-goldplate articles other than watchcases.

48-40. Domestic burners for Pennsylvania anthracite (underfeed type) (second edition).

49-34. Chip board, laminated chip board, and miscellaneous boards for bookbinding purposes.

50-34. Binders board for bookbinding and other purposes.

51-35. Marking articles made of silver in combination with gold.

52-35. Mohair pile fabries (100-percent mohair plain velvet, 100 -percent mohair plain frieze, and 50 -percent mohair plain frieze).

53-35. Colors and finishes for cast stone.

54-35. Mattresses for hospitals.

5.5-35. Mattresses for institutions.

56-41. Oak flooring (second edition)

57-40. Book cloths, buckrams, and impregnated fabrics for bookbinding purposes except library bindings (second edition).

58-36. Woven elastic fabrics for use in overalls (overall elastic webbing).

59-44. Textiles-testing and reporting (fourth edition).

60-36. Hardwood dimension lumber.

61-37. Wood-slat venetian blinds.

62-38. Colors for kitchen accessories.

63-38. Color for bathroom accessories.

64-37. Walnut veneers.

65-43. Methods of analysis and of reporting fiber composition of textile products (second edition).

66-38. Marking of articles made wholly or in part of platinum.

67-38. Marking articles made of karat gold.

68-38. Liquid hypochlorite disinfectant, deodorant, and germicide.

69-38. Pine oil disinfectant.

70-41. Phenolic disinfectant (emulsifying type) (second edition) (published with CS71 41).

71-41. Phenolic disinfectant (soluble type) (second edition) (published with CS70(si).

72-38. Household insecticide (liquid spray type)

73-45. Old growth Douglas fir standard stock doors (third edition)

74-39. Solid hardwood wall paneling.

75-42. Automatic mechanical draft oil bur ners designed for domestic installations (second edition).

76-39. Hardwood interior trim and molding.

77-40. Sanitary cast-iron enameled ware.

78-40. Ground-and-polished lenses for sunglasses (second edition) (published with CS7!) 40).
CS No.

Item

79-40. Blown, drawn, and dropped lenses for sun glasses (second editiou) (published with CS78-40).

80-41. Electric direction signal systems other than semaphore type for commercial and other vehicles subject to special motor vehicle laws (after market).

81-41. Adverse-weather lamps for vehicles (after nuarket).

82-41. Inmer-controlled spotlamps for vehicles (after market)

83-41. Clearance, marker, and identification lamps for vehicles (after market).

84-41. Electric tail lamps for vehicles (after market).

85-41. Electric license-plate lamps for vehicles (after market).

86-41. Electric stop lamps for vehicles (after market).

87-41. Red electric warning lanterns.

88-41. Liquid-burning flares.

89-40. Hardwood stair treads and risers.

90- . (Reserved for power shovels and cranes)

91-41. Factory-fitted Douglas fir entrance doors

92-41. Cedar, cypress and redwood tank stock lumber.

93-41. Portable electric drills (exclusive of high frequency)

(4-41. Calking lead.

95-41. Lead pipe.

96-41. Lead traps and bends.

97-42. Electric supplementary driving and pass ing lamps for vehicles (after market).

98-42. Artists' oil paints.

99-42. Gas floor furnaces-gravity circulating type.

100-44. Porcelain-enameled steel utensils (second edition).

101-43. Flue-connected oil-burning space heaters equipped with vaporizing pot-type burners.

102- . (Reserved for Diesel and fuel-oil engines)

103-42. Cotton and rayon velour (jacquard and

104-46. Warm-air furnaces equipped with vaporizing pot-type oil burners (second edition).

105-43. Mineral wool; locs g granulated, or felted form, in low-temperature installations.

106-44. Boys' pajama sizes (woven fabrics) (second edition).

107-45. Commercial electric-refrigeration condensing units (second edition).

108-43. Treading automobile and truck tires.

109-44. Solid-fuel-burning forced-air furnaces.

110-43. Tire repairs-vulcanized (passenger, truck, and bus tires)

111-43. Earthenware (vitreous-glazed) plumbing fixtures.

112-43. Homogeneous fiber wallboard.

113-44. Oil-burning floor furnaces equipped with vaporizing pot-type burners.

114-43. Hospital sheeting for mattress protection.

115-44. Porcelain-enameled tanks for domestic use.

116-44. Bituminized-fibre drain and sewer pipe.

117-44. Mineral wool; blankets, blocks, insulating cement, and pipe insulation for heated industrial equipment.

118-44. Marking of jewelry and novelties of silver.

(E) 119-45. ${ }^{1}$ Dial indicators (for linear measurements).

120-46. Standard stock ponderosa pine doors (second edition)

121-45. Women's slip sizes (woven fabrics).

122-45. Western hen lock plywood.

123-45. Grading of diamond powder

(E) 124-45.1 Master disks.

125-45. Prefabricated homes.

126-45. Tank mounted air compressors.

127-45. Self-contained mechanically refrigerated drinking water coolers.

128-45. Men's sport shirt sizes- woven fabrics (other than those marked with regular. neckband sizes)

129-46. Materials for safety.wearing apparel. 


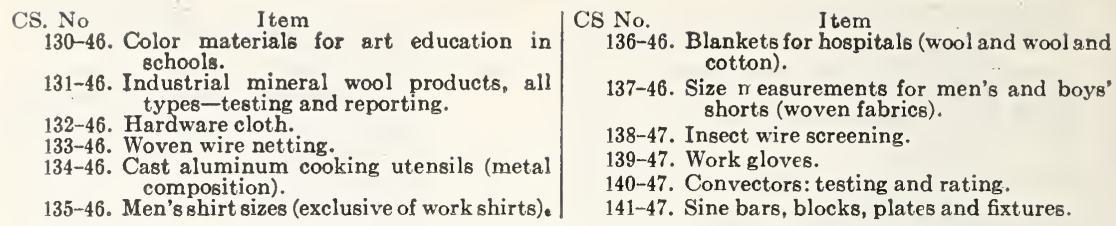

NoticE.-Those interested in commercial standards with a view toward accepting them as a basis of everyday practice may secure copies of the above standards, while the supply lasts, by addressing the Division of Trade Standards, National Bureau of Standards, Washington 25, D. C.

\footnotetext{
${ }^{1}$ Where "(E)" precedes the CS number, it indicates an emergency commercial standard, drafted under war conditions with a view toward early revision.
} 